\title{
An immunohistochemical study of gill epithelium cells in the Nile tilapia, Oreochromis niloticus
}

\author{
Sandra Mariza Monteiro1, António Fontainhas-Fernandes¹, Mário Sousa ${ }^{2,3}$ \\ ${ }^{1}$ Department of Biology and Environment - CITAB, University of Trás-os-Montes and Alto Douro, \\ Vila Real and ${ }^{2}$ Lab Cell Biology - ICBAS, University of Porto, Portugal \\ ${ }^{3}$ Centre for Reproductive Genetics Alberto Barros, Porto, Portugal
}

\begin{abstract}
This study reports the first complete mapping of the gill epithelium in a tilapia species. Different gill epithelial cell types of the Nile tilapia, Oreochromis niloticus L. have been identified and located using different antisera against mammalian proteins and various histochemical techniques: Periodic Acid Schiff (PAS), Alcian Blue pH 1.0, 2.5, 3.5, Giemsa and Grimelius. The results show that the stratified filament epithelium of $O$. niloticus gill can be divided into two distinct regions, a superficial layer, where pavement, mucous and mitochondria rich cells can be found, and a deep layer, constituted by undifferentiated, myoepithelial-like, granular and neuroendocrine cells. V-ATPase and $\mathrm{Na}^{+} / \mathrm{K}^{+}$-ATPase presence allowed the identification of pavement and mitochondria-rich cells, respectively, suggesting that, in $O$. niloticus, pavement cells are implicated in $\mathrm{Na}^{+}$uptake, whereas mitochondria-rich cells have a role in $\mathrm{Cl}^{-}$uptake. The use of PAS and Alcian Blue allowed the recognition of different sub-populations of mucous cells that differentiate from a common deeper precursor. Neuroendocrine markers were detected in different cell populations, stating evidence for a neuroendocrine role of mitochondria-rich cells, and suggesting the existence of distinct neural pathways, a putative $\mathrm{O}_{2}$-chemosensory and an ion regulatory pathway. A defence role was attributed to the deep filament epithelium, suggested by the presence of resident giemsa positive- eosinophil granular cells. The antibody raised against proliferating cell nuclear antigen identified two different cell types, the undifferentiated cells and myoepithelial-like cells. In the superficial layer, it is here stated for the first time the existence of vimentin positive support cells.
\end{abstract}

Key words: gills; mitochondria-rich cells, mucous cells, Oreochromis niloticus, Teleostei

\section{Introduction}

Fishes comprise about $50 \%$ of the known vertebrate species, which makes them an important resource for the development of relevant vertebrate models, as a replacement to mammals use in biomedical sciences, in monitoring aquatic pollution and toxicology. Nile tilapia, Oreochromis niloticus, is one of the most important freshwater fish in world aquaculture [1], it is a standard fish used in toxicity tests [2-5] and its utilization as a model for the study of mammal's physiological and pathological aspects is an open possibility.

Because of the reported variability in cellular composition and structure of tissues among different fish

Correspondence: S.M. Veiga Monteiro, Dept. of Biology and Environment, School of Life and Environment Sciences, University of Trás-os-Montes and Alto Douro, Apartado 1013, 5001-801 Vila Real, Portugal; tel.: (351) 2593502245,

e-mail: smonteir@utad.pt species [6,7], clarification of the normal histology of a particular species is of supreme importance in order to interpret the morphological and functional modifications occurring under pathological conditions. Fish gills constitute the largest fraction of the body surface area in direct contact with the water and, caused by ventilatory movement, a particularly high water volume bypasses the large gill surface. Since relevant physiological processes take place in the gills, such as gas exchange, osmoregulation, excretion of nitrogenous waste products and acid-base balance [6], disturbance of the structure of this organ compromises the survival of fish. In addition, the gills represent an appropriate model for the study of the potential environmental effects on the organism and, indirectly, may be used as an indicator of the degree of environmental contamination.

With respect to $O$. niloticus gill epithelium, only a few studies briefly described its normal histology [8] and characterized the ultrastructure of mitochondria- 
rich cells, under control and seawater adaptation conditions [9-13]. To our knowledge, there are no histochemistry or immunohistochemistry studies characterizing the different cell types present in this species gill. The histochemistry or immunohistochemistry are valuable tools in the identification and functional characterization of different cell types and, their use in the detection of environmental caused alterations may be of great value. To enable this hypothesis to be tested further the first step, and the main purpose of this study, was to characterize the cell population and their specific location in $O$. niloticus gill epithelium, a fish species often used as an indicator species. In addition, and using a battery of antisera, we intended to find new fish gill cell markers, thus contributing and complementing the current knowledge on the role of these cells in gill physiology, compelling their use as vertebrate models, substituting the utilization of mammal cells.

\section{Materials and methods}

Fish. Nile tilapia, Oreochromis niloticus (Linnaeus, 1758) were reared from the egg stage, in the Aquaculture Station of the University of Trás-os-Montes and Alto Douro (UTAD, Vila Real, Portugal), kept in $100 \mathrm{~L}$ recirculating tanks $(5 \mathrm{~L} / \mathrm{min}$ ) filled with dechlorinated tap water whose quality parameters (84/449/EEC Directives, Annex 5, method c1) were maintained by mechanical and biological filtration: $\mathrm{pH}$ 6.5-7.5, $60 \mathrm{mg} \mathrm{HCO3}-/ \mathrm{L}$ (alkalinity), 63 $\mu \mathrm{S} / \mathrm{cm}$ (conductivity), $14 \mathrm{mg} \mathrm{Na}^{+} / \mathrm{L}, 2.3 \mathrm{mg} \mathrm{K}^{+} / \mathrm{L}, 4.1 \mathrm{mg} \mathrm{Ca}^{2+} / \mathrm{L}$, $6.5 \mathrm{mg} \mathrm{Mg}^{2+} / \mathrm{L}, 19.5 \mathrm{mg} \mathrm{Cl}^{-} / \mathrm{L}, 27 \mathrm{mg} \mathrm{NO}_{3}-/ \mathrm{L}$ (nitrate), $0.5 \mathrm{mg}$ $\mathrm{NO}_{2}-/ \mathrm{L}$ (nitrite), $74.5 \mathrm{mg} \mathrm{CaCO} / / \mathrm{L}$ (hardness), $6.2 \mathrm{mg}$ dissolved $\mathrm{O}_{2} / \mathrm{L}, 21 \mathrm{mg} \mathrm{CO} / \mathrm{L}, 0.1 \mathrm{mg} \mathrm{H} \mathrm{H}_{2} \mathrm{~S} / \mathrm{L}$ (hydrogen sulfide), $0.7 \mathrm{mg}$ $\mathrm{NH}_{4}^{+} / \mathrm{L}$ (ammonia) and $12 \mathrm{mg}$ suspended solids/L. Supplemental aeration was provided to maintain dissolved oxygen near saturation, the temperature was kept at $25 \pm 1^{\circ} \mathrm{C}$ and the photoperiod controlled (12D:12L). Fish were fed once a day to visual satiation, with commercial fish food dry pellets (Aquasoja-Sorgal, Ovar, Portugal): $1.9 \%$ fibre, $4.3 \%$ lipids, $37.2 \%$ crude proteins, $2.2 \%$ $\mathrm{Ca}^{2+}, 1.4 \% \mathrm{P}$ and vitamins $\mathrm{A}, \mathrm{C}, \mathrm{D}_{3}$ and $\mathrm{E}$.

Tissue sampling and fixation. Experiments complied with European (86/609/EU) Guidelines for the correct use of laboratorial animals. A total of 20 tilapia of both sexes, ranging from 28.6 to 44 $\mathrm{g}$ of body weight, were anaesthetized with $1 \mathrm{ml}$ of 2-phenoxiethanol/L water (Sigma, Barcelona, Spain) and euthanized by decapitation. Gill filaments were immediately collected from the anterior and posterior aspects of the second gill arch of the right side of each fish. The excised gill filaments were fixed in buffered formaldehyde (Panreac, Barcelone, Spain), or Bouin's solution (Panreack, Barcelone, Spain), for $24 \mathrm{~h}$ at room temperature (22$26^{\circ} \mathrm{C}$ ). Following fixation, tissues were dehydrated, cleared in xylene and embedded in paraffin wax.

Histochemistry. The paraffin blocks were serially sectioned $(5 \mu \mathrm{m}$ thick) parallel to the long axis of the gill filament and the sections were collected onto either clean slides or APS-coated (3-aminopropyltriethoxysilane; Sigma Chemical Company) slides and air dried at $37^{\circ} \mathrm{C}$ overnight. The sections were then dewaxed in xylene baths, rehydrated through an ethanol series to distilled water, and stained with periodic acid-Schiff (PAS) reaction, Alcian Blue, Giemsa and Grimelius, for histochemistry.

For PAS reaction, the slides were rinsed in $1 \%$ periodic acid for 10 minutes, washed in running tap water for another 10 minutes, to remove all acid, and placed in Schiff's reagent (Merck, Darmstadt,
Germany) at room temperature during 20 minutes. Then the slides were washed again in running tap water and stained in hematoxylin for 1-2 minutes. Alcian Blue (AB) stains acidic groups or sulfated glycoconjugates and glycosaminoglycans and was used to differentiate these from the neutral mucins identified by the PAS reaction. Three serial sections were separately incubated in a $1 \%$ solution of $\mathrm{AB}$ in $0.5 \%$ acetic acid ( $\mathrm{pH} 3.1$ ), in a $1 \%$ solution of $\mathrm{AB}$ in $3 \%$ acetic acid $(\mathrm{pH} 2.5)$ and in a $1 \%$ solution of $\mathrm{AB}$ in $0.1 \mathrm{M} \mathrm{HCl}$ $(\mathrm{pH} 1.0)$, for 30 minutes at room temperature. Excess color was removed by running tap water and nuclear conterstain was done by immersion in haematoxylin for 1 minute. A positive reaction was identified by a Prussian blue colour. The detection of argyrophil cells was made accordingly to the microwave modification of the Pascual's method [14]. Briefly, after rehydration to citric acid glycine solution, slides were immersed in $0.5 \%$ silver nitrate solution and microwave at $400 \mathrm{w}$ for 1 minute. Slides were then rinsed in four changes of distilled water, transferred to Bodian's developer (Sodium sulfite anhydrous, Hydroquinone and distilled water) and microwave at $400 \mathrm{w}$ for 40 seconds approximately. After a new wash, rinsing in four changes of distilled water, the procedure was successively repeated until the evident detection of argyrophil cells. This procedure identifies most neuroendocrine cell types by deposition of metallic silver within the secretory granules that stain dark brown to black [15]. Following each staining procedure, the sections were dehydrated in graded alcohols, cleared in xylene and mounted with entellan (Merck). For Giemsa stain, the hydrated slides were incubated for 40 minutes in a Coplin jar with Giemsa stain. Giemsa solution was prepared by mixing $1.5 \mathrm{ml}$ Giemsa (Merck) with $50 \mathrm{ml}$ of distilled water. After staining, slides were washed in $95 \%$ ethanol, rinsed a few seconds in absolute ethanol, cleared in xylene and mounted with entellan. The giemsa stain is used to differentiate nuclear and/or cytoplasmic morphology of a variety of cells, including blood cells, platelets, red and white blood cells and parasites.

Immunohistochemistry. Immunohistochemistry was carried out using the avidin-biotin method (Vectastain Universal Elite ABC Kit, Vector Laboratories, CA, USA). The paraffin sections were collected onto APS-coated slides, air-dried at $37^{\circ} \mathrm{C}$ overnight, and dewaxed through a series of xylene baths and rehydrated through an ethanol series to distilled water. Then, they were dipped for 20 minutes in $0.3 \% \mathrm{H}_{2} \mathrm{O}_{2}$ (Merck) for endogenous peroxidase blocking. After rinsing 2 minutes each in tap water, distilled water and TPBS buffer $(0.05 \%$ Tween-20-phosphate-buffered saline, $\mathrm{pH}$ 7.2 ), sections were circled with a hydrophobic barrier (Dako Pen, Dako DK, Denmark) and blocked with normal horse serum (1:100) for 20 minutes at room temperature. Sections were then incubated with primary antisera diluted in $10 \%$ bovine serum albumin (BSA, Sigma). The primary antisera, working concentrations and incubation times used in this study are shown in the Table 1. Following $3 \times 2$ minutes washes in TPBS buffer, sections were incubated for 30 minutes with diluted biotinylated secondary antibody (1:50), washed in TPBS $(3 \times 2$ minutes) and incubated in avidin-biotincomplex for 30 minutes. Following rinsing in PBS buffer, sections were immersed in $0.05 \%$ of 3,3'-diaminobenzidine (DAB, Sigma) in PBS buffer containing $0.03 \% \mathrm{H}_{2} \mathrm{O}_{2}$. Subsequently, sections were rinsed for 10 minutes in tap water, counterstained with haematoxylin, dehydrated, cleared and mounted. Normal horse serum was routinely used as negative control to account for non-specific background labelling.

The antigen retrieval technique, employed to expose epitopes masked during tissue fixation, was used to enhance the immunoreactivity of tissue sections with the vimentin and synaptophysin antisera. The citric acid based - antigen unmasking solution (Vector Laboratories. Inc, Burlingame, USA) pre-treatment was conducted following dewaxing of paraffin and rehydration. The sections were submerged in $1 \%$ antigen unmasking solution in PBS, microwave (600w) for 10 minutes and washed in running tap water. 
Table 1. Antibodies used in the immunohistochemical study.

\begin{tabular}{|c|c|c|c|c|}
\hline Antibodics & Source & Concentration & $\begin{array}{l}\text { Incubation } \\
\text { time* }\end{array}$ & $\begin{array}{l}\mathrm{D} \wedge \mathrm{B} \\
\text { incubation time }\end{array}$ \\
\hline \multicolumn{5}{|l|}{ V-lype II+-ATPase } \\
\hline $\begin{array}{l}\text { Rabbit polyclonal antibody raised } \\
\text { against a synthetic peptide }\end{array}$ & $\begin{array}{l}\text { Kindly donated by J.M. Wilson, } \\
\text { CIIMAR, University of Porto, Porlugal }\end{array}$ & $1: 500$ & 60 minutes & 2 minules \\
\hline \multicolumn{5}{|l|}{$\mathrm{Na}+/ \mathrm{K}+-\mathrm{AlPase}$} \\
\hline Mouse monoclonal antibody & $\begin{array}{l}\text { Depart. of Biol. Sciences, University of } \\
\text { Iowa, US } \Lambda\end{array}$ & $1: 500$ & Overnight & 10 minutes \\
\hline \multicolumn{5}{|l|}{ C-Kit (CD117) } \\
\hline Polyclonal rabbit anti-human & Dako Cytomation $\wedge 4502$ & $1: 100$ & 30 minutes & 10 minutes \\
\hline \multicolumn{5}{|l|}{ Synaptophysin } \\
\hline Polyclonal rabbit anti-human & Dako Cytomation ADO10 & $1: 100$ & Ovemight & 10 minules \\
\hline \multicolumn{5}{|l|}{ PCNA } \\
\hline Mouse monoclonal antibody & Calbiochem $₫$ NA03 & $1: 4000$ & Overnight & 15 minutes \\
\hline \multicolumn{5}{|l|}{ Serotonin } \\
\hline $\begin{array}{l}\text { Polyclonal rabbit anti-serotonin } \\
\text { creatinine sulfate complex }\end{array}$ & Sigma S5545 & $1: 500$ & 60 minules & 2 minules \\
\hline \multicolumn{5}{|l|}{ Vimentin } \\
\hline Liquid mouse monoclonal & Novocastra ${ }^{\mathrm{TM}}$ NCL-L-VIM-V9 & $1: 100$ & 30 minules & 10 minules \\
\hline
\end{tabular}

*All antibodies were incubated at room temperature

Gill $\mathrm{Na}^{+} / \mathrm{K}^{+}$-ATPase was immunolocalized accordingly to peroxidase anti-peroxidase (PAP) method. After deparaffinization and rehydration, slides were rinsed in tap water and dipped for $15 \mathrm{~min}$ utes in $0.3 \% \mathrm{H}_{2} \mathrm{O}_{2}$ for endogenous peroxidase blocking (Merck). After rinsing 5 minutes each in tap water, distilled water and Tris buffer (Merck), sections were incubated for 18 hours at $22^{\circ} \mathrm{C}$ with 1:500 primary antibody. After $3 \times 5$ minutes washes in Tris buffer, sections were incubated for 60 minutes with 1:40 goat-anti-mouse IgG1 secondary antibody and then for 45 minutes in 1:100 PAP complex (Sigma). After rinsing in Tris buffer, sections were immersed for 10 minutes in $0.05 \%$ of 3,3'-diaminobenzidine in Tris buffer containing $0.03 \% \mathrm{H} 2 \mathrm{O} 2$ (Sigma). Subsequently, sections were rinsed for 10 minutes in tap water, dehydrated, cleared and mounted. Antisera and PAP complex were diluted in Tris buffer, $\mathrm{pH} 7.8$, containing $0.7 \%$ non-gelling seaweed gelatin, lambda carrageenen, $0.5 \%$ Triton $\mathrm{X}-100$ and $0.02 \%$ sodium azide (Sigma). For negative controls the primary antibody was omitted.

Antibodies. To characterize and localize the cell populations present in $O$. niloticus gill epithelia, we used antibodies raised against the proteins described below. A brief description of their function will be provided to facilitate the results interpretation.

The apical electrogenic vacuolar-type $\mathrm{H}^{+}$-ATPase (V-ATPase) pumps protons across the apical membrane, creating a membrane potential capable of driving passive $\mathrm{Na}^{+}$influx via an amiloride sensitive channel against its concentration gradient [16]. This enzyme is involved in freshwater fish osmoregulation and it was already immunolocalized to the apical membrane of pavement cells $[16,17]$. Mitochondria-rich cell (MRC) identification was made using a mouse monoclonal antibody raised against a chicken synthetic peptide corresponding to part of the highly conserved region of the $\mathrm{Na}^{+} / \mathrm{K}^{+}$-ATPase $\alpha$-subunit. This antibody is now in routine use for identifying gill MRC [18]. C-Kit is a transmembrane receptor kinase that has a broad physiological function, mediated in part by the interaction with its ligand, the stem cell factor (SCF) [19-21]. C-kit expression, mainly studied in mammals, was reported in various developing or differentiated cell types [22] and has been linked to the promotion of cellular migration, proliferation and/or survival, differentiation, adhesion, chemotaxis and functional activation [19]. Synaptophysin is a major transmembrane glycoprotein present in the membrane of neuronal presynapic vesicles and in synaptic-like microvesicles of the neuroendocrine cells [23]. The synaptophysin is implicated in the control of exocytosis and neurotransmitter release and represents a reliable general marker of neuroendocrine cells [24].

Serotonin (5-hydroxytryptamine, or 5-HT) is a monoamine neurotransmitter synthesized in serotonergic neurons and a broad neuroendocrine cell (NEC) marker, which expression was previously reported in fish gill epithelia [25-27]. Proliferating cell nuclear antigen (PCNA) is a highly conserved protein in eukaryotes and is expressed during cell proliferation and repair [28, 29]. The protein has long half-life, and a dark granular staining in nucleus may correspond more closely to the S-phase of the cell cycle [29]. Vimentin is an intermediate filament protein initially described in mesenchymal derivatives. It is co-located in immature cells with other kinds of intermediate filaments at particular stages of development or differentiation and is transiently expressed in various cell types during embryonic development (see [30] for references). Additionally, the clone V9 was recently shown to express in tilapia differentiating cells [31].

\section{Results}

The $O$. niloticus gill was covered by a two layer lamellar epithelium and a stratified filament epithelium. In the filament epithelium two distinct regions could be 

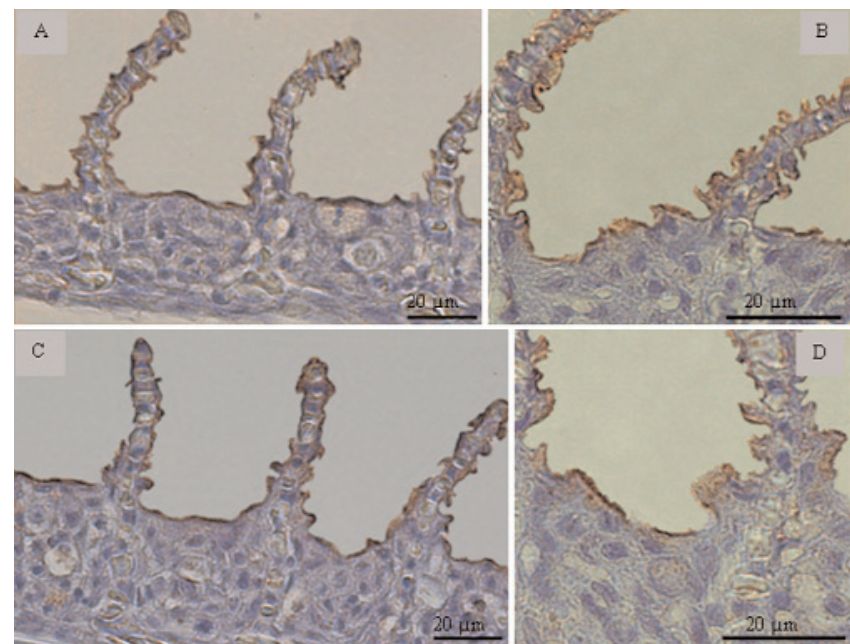

Fig. 1. Pavement cells V-ATPase positive. The figure clearly shows, at inferior (A and $\mathbf{C})$ and higher (B and $\mathbf{D})$ magnifications, the location of pavement cells at the superficial region, covering the filament and lamellar epithelia. $\mathrm{Bar}=20 \mu \mathrm{m}$.

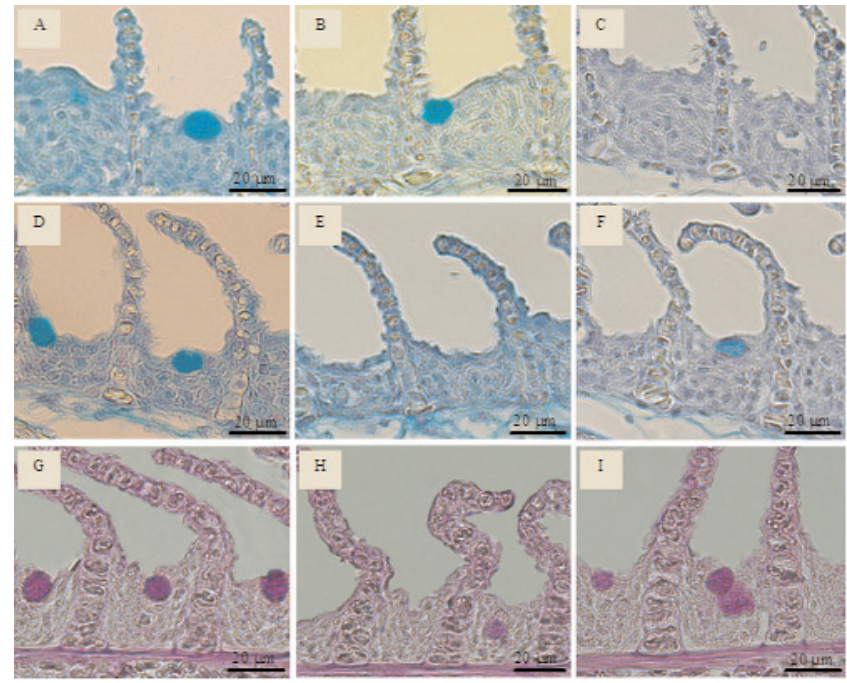

Fig. 2. Localization of mucous cells in the superficial regions of the gill filament epithelium. A-C. Serial sections stained with AB at $\mathrm{pH} 3.1,2.5$ and 1.0, respectively. D-F. Gill filament serial sections stained with $\mathrm{AB}$ at $\mathrm{pH}$ of $3.1,2.5$ and 1.0 , respectively. Note that different cells are stained with the different ranges of $\mathrm{pH}$ dyes, reflecting the dissimilar composition in acid mucosubstances and acetic mucins. G-I. PAS-positive mucous cells in superficial ( $\mathbf{G}$ and $\mathbf{I})$ and deeper regions ( $\mathbf{H}$ and $\mathbf{I})$ of the filament epithelium, possibly reflecting the presence of precursor mucous cells. $\mathrm{Bar}=20 \mu \mathrm{m}$.

observed, a superficial layer, essentially constituted by columnar cells and externally covered by squamous cells, and a deep layer, formed by undifferentiated cells and other distinct cell types.

The rabbit polyclonal anti-peptide antibody to the A-subunit of the V-ATPase cross-reacted with the squamous epithelial pavement cells (PVC), that were observed covering the lamellae and constituting the superficial layer of the stratified filament epithelium (Fig. 1).
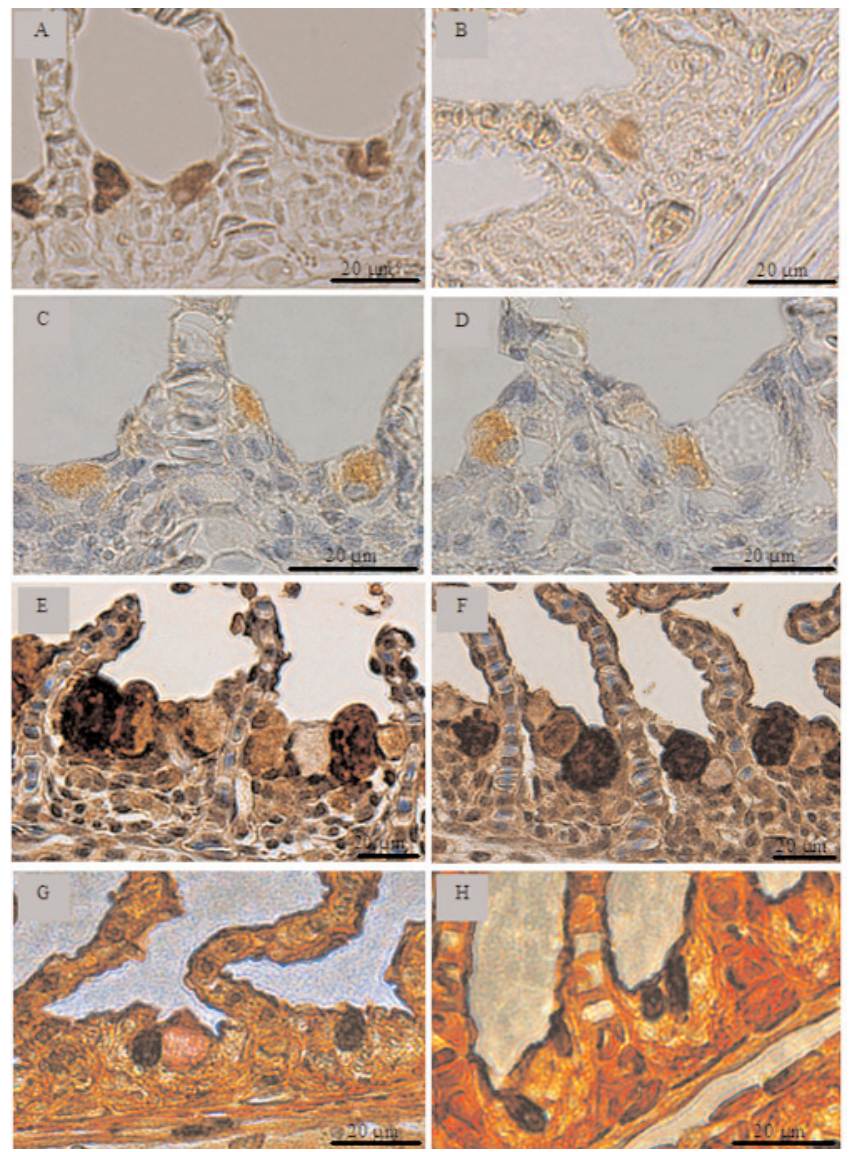

Fig. 3. Localization of mitochondria-rich cells in the superficial region of the filament epithelium. A-B. $\mathrm{Na}^{+} / \mathrm{K}^{+}$-ATPase positive cells located in the middle region of the superficial interlamellar space and near the lamellar vascular axis. Note a $\mathrm{Na}^{+} / \mathrm{K}^{+}$-ATPase positive cell (B) deeper in the epithelium and stained with less intensity, suggesting a mitochondria-rich precursor cell. C-D. c-kit (CD117)-positive cells in the same location of $\mathrm{Na}^{+} / \mathrm{K}^{+}$-ATPase positive cells. E-F. Synaptophysin positive cells also placed in the superficial region of the filament epithelium, intercalated with mucous cells and staining with different intensities. G-H. Grimelius positive with same location as the ones above. Bar $=20 \mu \mathrm{m}$.

The $\mathrm{AB}$ and PAS techniques, that identify acidic and neutral mucosubstances, respectively, co-localized mucous cells (MC). This cell type was observed mostly in the superficial region of the filament epithelium, in contact with the external milieu. The sequence of procedures utilizing $\mathrm{AB}$ at different $\mathrm{pH}$ levels showed distinct patterns of cells localization (Figs. 2A-C, 2D$\mathrm{F})$, demonstrating a dissimilar composition in strong and weakly sulfated acid mucopolysaccharides.

Although it was never observed in AB- positive cells, some PAS- positive cells, which stained with less intensity, were observed deeper in filament epithelium (Fig. 2H,I). Their localization and the inferior reactivity to PAS, probably indicate that these are not fully differentiated cells, migrating to the superficial region. Additionally, the fact that these cells do not react with $\mathrm{AB}$, may be indicative of a different constitution in 

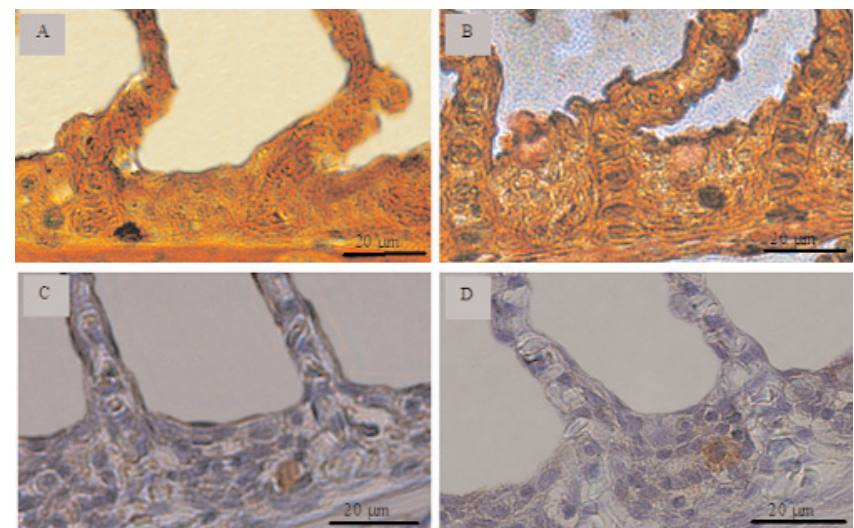

Fig. 4. Neuroepithelial cells located in the deeper region of the $O$. niloticus gill epithelium. A-B. Grimelius-positive neuroepithelial cells close to the basal membrane (A) and located in the central region, close to the superficial filament epithelium. C-D. Serotonin-positive cells with the same location observed in Grimeliuspositive cells. Bar $=20 \mu \mathrm{m}$.
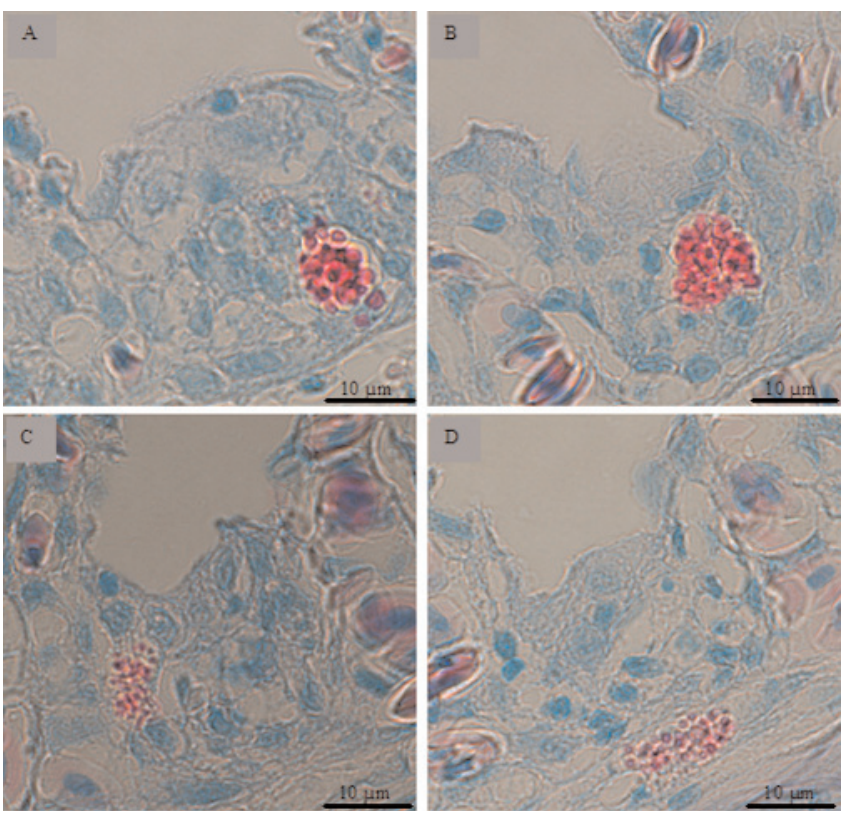

Fig. 5. Giemsa coloration evidencing the presence of eosinophile granule cells in filament epithelium of $O$. niloticus gill. A-C. Images showing the different locations of the cells and their different sizes cytoplasmatic granules. D. An eosinophile granule cell located in the connective tissue beneath the filament epithelium. Bar $=10 \mu \mathrm{m}$.

mucins, as the cells mature. Neither, PAS- nor ABpositive cells were observed in lamellar epithelium of the $O$. niloticus gill.

The mouse monoclonal antibody to the $\alpha$-subunit of the $\mathrm{Na}^{+} / \mathrm{K}^{+}-$ATPase, the rabbit polyclonal antibody to the transmembrane glycoprotein receptor (c-kit, also known as CD117), which belongs to the subclass III family of tyrosine kinase receptors, the polyclonal rabbit anti human synaptophysin and also the histochemical technique Grimelius, reacted positively with superficial columnar to ovoid cells (Fig. 3). The
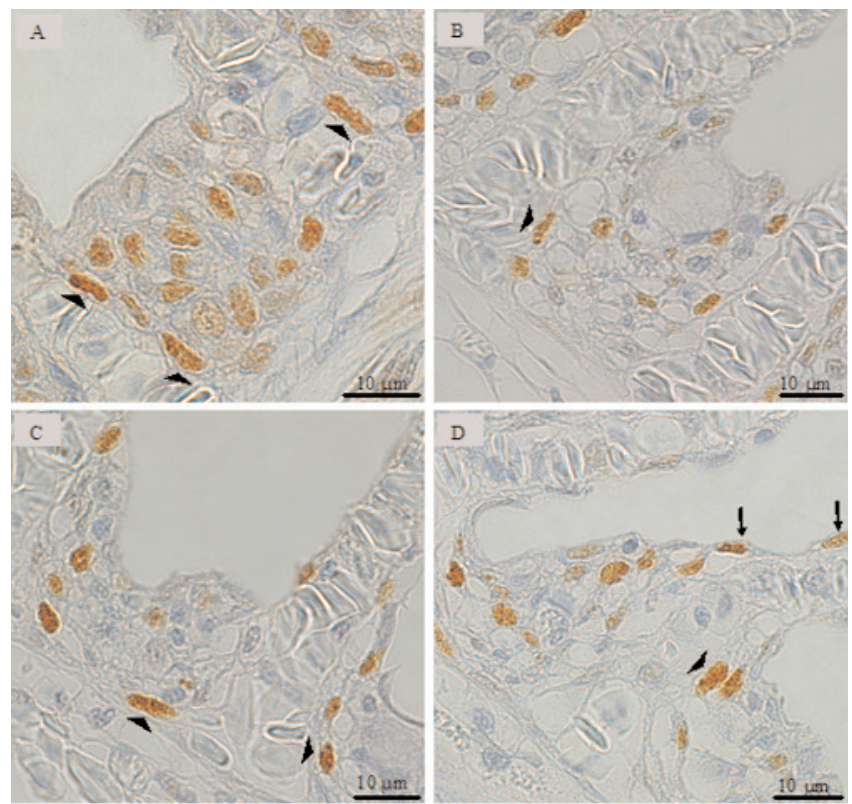

Fig. 6. PCNA immune-positive cells. A-B. The preferential location of undifferentiated PCNA positive cells in the deep region of the filament epithelium, also showing the presence of myoepithelial-like cells (arrowhead) at the epithelial base and in contact with arterial lamellar vasculature. C-D. Evidence for the presence of myoepithelial-like cells (arrowhead) at the base and lateral regions of the filament epithelium, as if they delimit the interlamellar space. Migration of this cell type to the lamellar epithelium, locating under the pavement respiratory cells (arrows). Bar $=10 \mu \mathrm{m}$.
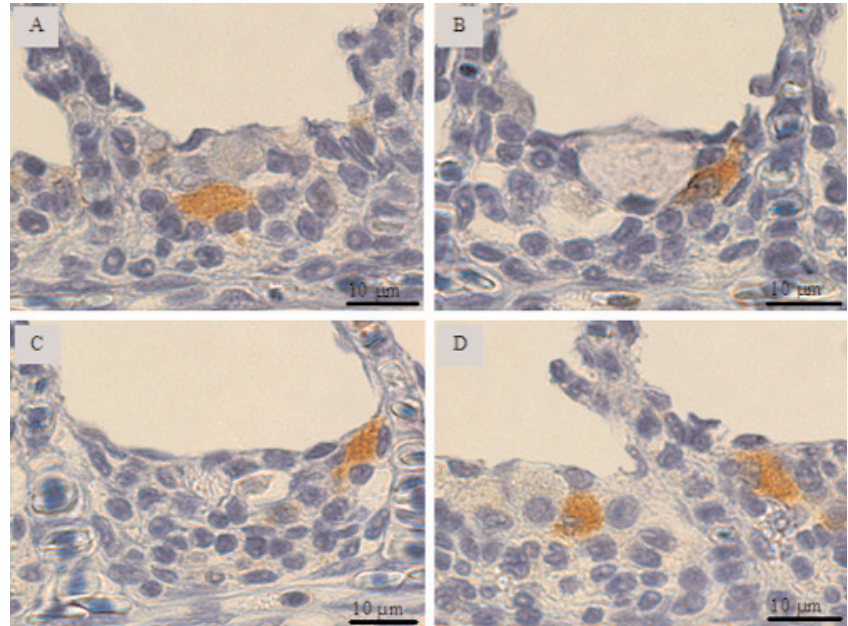

Fig. 7. Vimentin-positive cells preferentially located in the basal region of the superficial columnar epithelium (A, B and D) but also more superficially, in the lateral region of the superficial interlamellar epithelium, near of the lamellar vascular axis (C and $\mathbf{D})$. Bar $=10$ um.

immunopositive cells were strongly labeled and are frequently found in the middle region of the interlamellar spaces of the filament epithelium, intercalated with mucous cells, and laterally in the lamellar insertion site, in close contact with the lamellar arterial vascular system. The apical region of these cells faced the external water whereas, basally, they connect with 
Table 2. Tested antibodies that failed to induce positive results.

\begin{tabular}{|c|c|c|c|c|}
\hline $\begin{array}{c}\text { Pavement } \\
\text { cells }\end{array}$ & $\begin{array}{c}\text { Undifferentiated } \\
\text { cells }\end{array}$ & $\begin{array}{c}\text { Neuroendocrine } \\
\text { cells }\end{array}$ & $\begin{array}{c}\text { Macrophagic } \\
\text { cells }\end{array}$ & $\begin{array}{c}\text { Myoepithelial } \\
\text { cells }\end{array}$ \\
\hline $\mathrm{MNI}$ & $\mathrm{CD} 34$ & Cromogranin A & CD68 & $\begin{array}{c}\alpha \text {-smooth muscle } \\
\text { actin }\end{array}$ \\
\hline & & Neuron specific enolase (NSF) & Myeloperoxidase & Cytoqueratin 903 \\
\hline & & Neurolilaments & & Calponin \\
\hline & & & & Specific muscle actin \\
\hline
\end{tabular}

other deeply located cell types. No positive labeling was observed in lamellar epithelium. Mucocytes that have a similar shape and that also appeared in the interlamellar spaces of the filament epithelium showed no labeling (Fig. 3D, E, G).

Although less intense, positivity to $\mathrm{Na}^{+} / \mathrm{K}^{+}-$ATPase was also observed in smaller cells, positioned slightly deeper in the superficial region of the filament epithelium (Fig. 3B). These cells were more rounded in appearance, with less quantity of cytoplasm and were never observed in contact with the water. The remaining antibodies did not label these cells. The polyclonal rabbit anti-human synaptophysin, an acidic $\mathrm{Ca}^{2+}$ binding glycoprotein, reacted intensely, staining the cytoplasm vesicles dark brown in some superficial columnar cells and light brown in other cells (Fig. 3E, F). However, no preferential location was observed in these different labeled cells, being both observed in the middle region of the interlamellar space and close to lamellar vascular axis. None of the referred antibodies reacted with cells localized in the deep region of the filament epithelium.

Besides the superficial columnar cells (Fig. 3G, H), Grimelius also positively stained a rounded to ovoid cell type, deeply located in the filament epithelium (Fig. 4A, B). Additionally, polyclonal rabbit anti-serotonin creatinine sulfate complex also positively reacted with these cells (Fig. 4C, D), that were located either in the baso-lateral region of the deep filament epithelium, in close contact with the basement membrane (Fig. 4A, C), or in the central region, near the base of the superficial columnar epithelium (Fig. 4B, D). Adjacent sections treated with primary antisera to human chromogranin A, neuron-specific enolase and neurofilaments presented negative immunoreactions.

Giemsa allowed the identification of granular cells, with irregular shape and whose cytoplasm granules colored pink. The granules varied in size, being observed cells with big (Fig. 5A), intermediate (Fig. 5B) and small (Fig. 5C) granules. These cells were located all around in the deep region of the filament epithelium, independently of the granules size, and were never observed superficially, in contact with the external milieu, or in lamellar epithelium. Granular Giemsa-positive cells were also observed in the connective tissue beneath the basement membrane of the filament epithelium (Fig. 5D). The cells with this location had cytoplasm granules with homogenous small size.

The mouse monoclonal antibody raised against proliferating cell nuclear antigen (PCNA), labeled small cells with rounded nucleus, scattered preferentially through the deep region of the filament epithelium (Fig. 6A, B). Besides these ones, this antibody also labeled a cell type with an elongated nucleus and located deeply in the filament epithelium, in close contact with the basement membrane (Fig. 6C). These cells were also observed in the lateral regions of the interlamellar space, accompanying the ascending vascular axis of the lamellae (Fig. 6A, C), and in the lamellar epithelium, beneath the respiratory pavement cells (Fig. 6D). Although these deep cells morphologically resemble myoepithelial cells, they did not react to specific markers for muscle cells, such as $\alpha$-smooth muscle actin, cytoqueratin 903, calponin and muscle-specific actin (see Table 2).

Monoclonal anti-Vimentin antibody labeled ovoid cells preferentially located in the basal region of the superficial columnar filament epithelium (Fig. 7A, D), flanking mucous and mitochondria-rich cells, sometimes emitting cytoplasmic projections to the surface (Fig. 7B). Although more rarely, these cells could also be observed more superficially, near the lamellar insertion region (Fig.7C, D). However, they were never seen in direct contact with the external milieu or in the lamellar epithelium.

\section{Discussion}

The V-ATPase antibody was previously shown to react with the apical membrane of gill PVC [17]. In $O$. niloticus, it also labeled PVC that covered the great majority of the filament and lamellar epithelia. Due to their predominant location in lamellae, the main site of respiratory gas exchange, for long, this has been the sole function attributed to PVCs. However, posterior studies indicated that these cells are also involved in hydromineral balance and are responsible for ion transport [17,32-37]. They have specifically been implicated in osmotic regulation, as the site of $\mathrm{Na}^{+}$ 
uptake via channels electrically associated with the $\mathrm{H}^{+}$-ATPase of the apical membrane [16,38-40] and thus, directly coupled to acid-base regulation. They also have been suggested to be the dominant site for both $\mathrm{Na}^{+}$and Cl- transport pathways [41], to have a role in $\mathrm{Ca}^{2+}$ uptake [42] or to contribute only to epithelium surface protection [33,43-45]. In the present study, the observed immune-reactivity of V- ATPase in $\mathrm{PVC}$ and not in MRC, suggests that in $O$. niloticus, as in O. mossambicus [16], the PVC and not MRC are the site for $\mathrm{Na}^{+}$uptake, attributing this function not only to filament but also to lamellar PVC.

The combination of $\mathrm{AB}$ and PAS staining revealed, for the first time, the existence of different sub-types of $\mathrm{MC}$, with a distinct chemical composition, in the filament epithelium of $O$. niloticus. This is in agreement with results reported in Micropogonias furnieri and in Coelorhynchus coelorhynchus gills, where MC showed glycoproteins and acid proteoglycans with sulphate or carboxyl groups [46-48]. Lectin histochemistry was also used to describe different subpopulations of MC in Salmo trutta and Oncorhynchus mykiss [49,50]. Taken together, all these results suggest that the different subpopulations of MC found in the gill epithelium, contribute to heterogeneity in the mucus chemical composition, that can be correlated to the diverse functions attributed in the processes of gas and ion exchange, binding and uptake of xenobiotics and in the defense against infectious agents. Conversely, the variation in mucosubstances constitution is not reflected in MC-precursors, since these cells were observed with PAS staining but not with $\mathrm{AB}$, suggesting that, in this species, they differentiate from a common precursor.

The distribution of $\mathrm{Na}^{+} / \mathrm{K}^{+}$-ATPase, determined using the mouse monoclonal antibody to the $\alpha$-subunit, is restricted to MRC, a population of columnar cells localized in the superficial layer of the filament epithelium, either in the middle region of the interlamellar space or at the junctions between the filament and lamella. The defining features of this cell type are a high mitochondrial density and the presence of a cytoplasmic tubular system to which the ionoregulatory enzyme $\mathrm{Na}^{+} / \mathrm{K}^{+}$- ATPase is associated [6,7,38]. Accordingly, $\mathrm{MRC}$ are essential in fish osmoregulation and convincing evidence exists that, in $O$. mossambicus, they are mainly responsible for Cl- uptake [16]. This fact is here confirmed, in $O$. niloticus, due to the observed absence of labeling to V-ATPase. In addition, the use of this antibody, amply recognized as a MRC marker, allowed the identification of smaller rounded cells, less intensely stained, located deep in the superficial layer of the filament epithelium, confirming the differentiation of MRC from the basal epithelial cells. However, and contrary to what have previously been observed in other teleost species [38], no MRC were observed in lamellar epithelium.
In addition to $\mathrm{Na}^{+} / \mathrm{K}^{+}$-ATPase, different cell markers have co-localized MRC, possibly reflecting a role of this cell type in other functions beyond the well recognized osmoregulatory function. The immunolocalization of c-Kit, generally used as a proliferation and/or differentiation marker, was observed in MRC cytoplasm. Its expression was also previously detected in Danio rerio neural crest-derived melanocytes, revealing an evolutionary divergence across phylogenetic lineages [51]. However, in O. niloticus, this divergence is not evident. Indeed, cytoplasmic expression of c-kit was also observed in human's renal intercalated cells, [52] which are known to have similar functions and ultrastrutural features, thus suggesting a common function to c-kit. On the other hand, c-kit expression was not observed in the differentiating MRC, localized by the $\mathrm{Na}^{+} / \mathrm{K}^{+}$- ATPase antibody and, in addition, PCNA and vimentin, also known as undifferentiated cells markers, did not co-localized MRC. These results may be indicative that, in $O$. niloticus, ckit is not implicated in MRC proliferation or differentiation. Instead, it can act as a survival factor or be responsible for their connection/interaction to PVC, as well as for their migration induced by changes in environmental conditions [7]. In addition, its expression in cells of neuronal origin [53] and in neuroendocrine cells [54], previously reported in rats, as well as its present co-localization with the synaptophysin, a known neuroendocrine marker, may reveal a role of the c-kit/SCF axis in the development of MRC neuroendocrine functions.

Actually, a neuroendocrine role, suggested by the synaptophysin antibody reaction with $\mathrm{MRC}$, is not excluded by the fact that other neuroendocrine markers, such as cromogranin A, neuron specific enolase and neurofilaments have not co-localized these cells. Indeed, the synaptophysin expression is not dependent on the synthesis of other markers of neuroendocrine differentiation [24]. Re-enforcing this hypothesis are the studies of other authors that demonstrated the occurrence of so-called open-type neuroendocrine cells (NEC), with immunoreactivities for met-5enkephalin and leu-5-enkephalin [27,55]. The location of the referred cells was the same observed in the present work and their ultrastructural characteristics [55] closely resembled the ones of MRC [38]. In addition, Grimelius that stains most NEC types, co-localized the synaptophysin positive cells, reinforcing the idea that these cells perform a neuroendocrine function. Moreover, in zebrafish, the gill nerve fibres are associated with the basolateral regions of MRC, suggesting that putative presynaptic nerve terminals release neurochemicals to influence the activity of membranebound ion channels [56]. Thereby, synaptophysin may be involved in the control of ion regulation across the gill epithelium. 
Another NEC type, occurring in the basal layer of the filament epithelium, was stained by Grimelius. These cells were also serotonin-positive and have previously been reported as a component of the gill filament epithelium of other teleostean [25,27] and holostean [26] species. The ovoid cells were located deeply in the filament epithelium near the basement membrane or in the vicinity of the superficial epithelial layer but never contacted with the external surface. They have been implicated in $\mathrm{O}_{2}$ chemoreception and respiratory regulation in fish [57]. Accordingly to what have been said, and as serotonin and synaptophysin do not coexist in the same NEC, the present results support the existence, in O. niloticus, of two neural pathways; a putative $\mathrm{O}_{2}$-chemosensory pathway, through which serotonin positive NEC stimulated by hypoxia may communicate with the nervous system, and an ion regulatory neural pathway, that may be associated with both efferent and sensory innervation [58].

In the present study, Giemsa stain allowed the identification of granular cells whose acidic citoplasmic granules stained pink. These cells were scattered through the deep layer of the filament epithelium, showing cytoplasmic granules of different sizes. Cells with uniform small sized granules were also observed in the connective tissue beneath the gill epithelium. The possibility of being neutrophils or macrophages was excluded by the negative results obtained with the use of antibodies against myeloperoxidase, a recognized neutrophil marker, and against the macrophage antigen CD68, both known to express in fish $[59,60]$. Previous reports have described granular cells in the gills of different teleost families. These, constitute a heterogeneous cell population, which is exemplified by their variable morphology, granular content, sensitivity to fixatives, and response to drugs. Because of this, different authors have referred to them in different species as mast cells, basophilic granular cells, or acidophilic/eosinophilic granule cells $[61,62]$. Eosinophilic granule cells are generally thought to be involved in the non-specific innate defense systems of fish and have been shown to degranulate in response to numerous immunological challenges [61]. On activation, the EGCs of teleosts can release or produce substances involved in the acute inflammatory reaction [62] and in stimulating neutrophil migration to sites of inflammation [63]. In persistent inflammatory reactions, recruitment and accumulation of EGCs was also observed $[64,65]$. However, except for a study that reported the presence of both mast cells and eosinophil granulocytes in gill epithelium [66], their presence was mainly described in the connective tissue [62]. In opposition, in the present study, the granular cells were mainly observed in the filament epithelium and, due to their similar staining characteristics, we believe that these cells are members of a resident population and that the different granules size corresponds to different maturation stages. Supporting this hypothesis is the work of [67] that also observed mature eosinophil granule cells in mitosis and in different development stages. However, we can not exclude the possibility of being eosinophilic granulocytes that invade the tissue at its immature stage and mature into a secretory cell in response to the appropriate stimuli.

The PCNA antibody, previously used in fish gill to identify undifferentiated cells [68], recognized in $O$. niloticus, two different cell types, the commonly observed undifferentiated cells, with a rounded nucleus and a high nucleus to cytoplasm ratio, and cells with a flattened nucleus and elongated cytoplasmic extensions, resembling myoepithelial cells. Confirming the statements of other authors, the former cells were found scattered through the deep layer of the filament epithelium and differentiate in other epithelial cell types $[7,69]$. Smaller and less immunoreactive cells were also observed in the basal part of the superficial filament layer. On the other hand, myoepithelial-like cells coated the lateral surfaces of the deep epithelial layer, suggesting a role in the synthesis of the basal lamina or in the contractile regulation of the lamellar capillary axis. Although less frequent, undifferentiated cells were also observed in lamellar epithelium in direct contact with pillar cells basement membrane, thus corroborating previous results in Trichogaster leeri [70]. These cells had an elongated nucleus, similar to the ones of the myoepithelial-like cells, which may suggest a similar role or a common differentiation in pillar cells, also known to have a contractile function [71].

In the present study, vimentin positive cells are demonstrated for the first time in the gill filament epithelium of O. niloticus. Due to their position, flanking the superficial columnar cells and contacting the basal face of pavement cells, we may suggest a structural supporting role for this cell type. In addition, they may also represent a transient differentiation stage of other cell types superficially located, namely pavement cells, which once differentiated no longer express the protein vimentin.

In conclusion, our study shows that the stratified filament epithelium of $O$. niloticus gill can be separated into two distinct regions, the superficial layer, where PVC and the columnar MC and MRC can be found, and the deep layer, with characteristics of connective tissue, constituted by undifferentiated, myoepithelial-like, granular and NE cells. It clearly demonstrates the existence of different sub-populations of $\mathrm{MC}$, that differentiate from a common deeper precursor and states evidence for a neuroendocrine role of MRC, thus suggesting the existence of distinct neural pathways, a putative $\mathrm{O}_{2}$-chemosensory and a ion regulatory pathway. A putative defense role is also attrib- 
uted to the deep filament epithelium, suggested by the presence of resident eosinophil granular cells. In the superficial layer, it is here stated for the first time the existence of vimentin positive support cells.

Acknowledgments: We acknowledge R. Henrique, from the oncologic portuguese institute, for the immunostaining training and J.M. Wilson, from CIIMAR, for the kindly donated antibody against V-type- $\mathrm{H}^{+}$-ATPase. This work was financially supported in part by Fundation for Science and Technology (SFRH/ BD/6785/2001; POCI/SAU-MMO/60709/60555/59997/04; UMIB).

\section{References}

[1] Rakocy JE. FAO c2005-2008. Cultured Aquatic Species Information Programme - Oreochromis niloticus. 2008. In FAO Fisheries and Aquaculture Department. Rome. Available at: http://www.fao.org/fishery/culturedspecies/Oreochromis niloticus. Accessed 06 Oct 2008

[2] Garcia-Santos S, Fontaínhas-Fernandes A, Wilson JM. Cadmium Tolerance in the Nile Tilapia (Oreochromis niloticus) Following Acute Exposure: Assessment of Some Ionoregulatory Parameters. Environm Toxicol. 2006;21:33-46.

[3] Monteiro SM, Mancera JM, Fontaínhas-Fernandes A, Sousa M. Copper induced alterations of biochemical parameters in the gill and plasma of Oreochromis niloticus. Comp Biochem Physiol. 2005;141(C):375-383.

[4] Monteiro SM, Rocha E, Mancera JM, Fontaínhas-Fernandes A, Sousa, M. A stereological study of copper toxicity in gills of Oreochromis niloticus. Ecotoxicol Environ Saf. 2008; 72:213-223.

[5] Shaw BJ, Handy RD. Dietary copper exposure and recovery in Nile tilapia, Oreochromis niloticus. Aquat Toxicol. 2006;76:111-121.

[6] Evans DH, Piermarini PM, Choe KP. The multifunctional fish gill: dominant site of gas exchange, osmoregulation, acidbase regulation, and excretion of nitrogenous waste. Physiol Rev. 2005;85:97-177.

[7] Wilson JM, Laurent P. Fish gill morphology: inside out. J Exp Zool. 2002;293:192-213.

[8] Zayed AE, Mohamed SA. Morphological study on the gills of two species of fresh water fishes: Oreochromis niloticus and Clarias gariepinus. Ann Anat. 2004;186:1-10.

[9] Avella M, Berhaut J, Bornancin M. Salinity tolerence of two tropical fishes, Oreochromis aureus and O. niloticus. I. Biochemical and morphological changes in the gill epithelium. $J$ Fish Biol. 1993;42:243-254.

[10] Cioni C, De Merich D, Cataldi E, Cataudella S. Fine structure of chloride cells in freshwater- and seawater-adapted Oreochromis niloticus (Linnaeus) and Oreochromis mossambicus (Peters). J Fish Biol. 1991;39:197-209.

[11] Maina JN. A study of the morphology of the gills of an extreme alkalinity and hyperosmotic adapted teleost Oreochromis alcalicus grahami (Boulenger) with particular emphasis on the ultrastructure of the chloride cells and their modifications with water dilution. A SEM and TEM study. Anat Embryol. 1990;181:83-98.

[12] Maina JN. A morphometric analysis of chloride cells in the gills of the teleosts Oreochromis alcalicus and Orechromis nilotocus and a description of presumptive urea-excreting cells in O. alcalicus. J Anat. 1991;175:131-145.

[13] Pisam M, Le Moal C, Auperin B, Prunet P, Rambourg A. Apical structures of mitochondria-rich $\alpha$ and $\beta$ cells in euryhaline fish gill: their behaviour in various living conditions. Anat Rec. 1995;241:13-24.

[14] Churukian CJ. Microwave modification of Pascual's argyrophil method. Histologic. 1989;19:121-123.
[15] Grimelius L. Silver stains demonstrating neuroendocrine cells. Biotech Histochem. 2004;79(1):37-44.

[16] Wilson JM, Laurent P, Tufts BL, Benos DJ, Donowitz M, Vogl AW, Randall DJ. NaCl uptake by the branchial epithelium in freshwater teleost fish: an immunological approach to ion-transport protein localization. J Exp Biol. 2000;203:22792296.

[17] Sullivan GV, Fryer JN, Perry SF. Immunolocalization of proton pumps $\left(\mathrm{H}^{+}\right.$-ATPase $)$in pavement cells of rainbow trout gill. J Exp Biol. 1995;198:2619-2629.

[18] Lee TH, Tsai JC, Fang MJ, Yu MJ, Hwang PP. Isoform expression of $\mathrm{Na}^{+}-\mathrm{K}^{+}$-ATPase a-subunit in gills of the teleost Oreochromis mossambicus. Am J Physiol. 1998;275:R926R932.

[19] Ashman LK. The biology of stem cell factor and its receptor C-kit. Int J Biochem Cell Biol. 1999;31:1037-1051.

[20] Qiu F, Ray P, Brown K, Barker PE, Jhanwarl S, Ruddle FH, Besmer P. Primary structure of c-kit: relationship with the CSF-1/PDGF receptor kinase family-oncogenic activation of c-kit involves deletion of extracellular domain and $\mathrm{C}$ terminus. EMBO J. 1988;7:1003-1011.

[21] Yarden Y, Kuang W-J, Yang-Feng T, Coussens L, Munemitsul S, Dull TJ, Chen E, Schlessinger J, Francke U, Ullrich A. Human proto-oncogene c-kit: a new cell surface receptor tyrosine kinase for an unidentified ligand. EMBO J. 1987;6:3341-3351.

[22] Lammie A, Drobnjak M, Gerald W, Saad A, Cote R, CordonCardo C. Expression of c-kit and kit ligand proteins in normal human tissues. J Histochem Cytochem. 1994;42:1417-1421.

[23] Edelmann L, Hanson P, Chapman ER, Jahn R. Synaptobrevin binding to synaptophysin: a potential mechanism for controlling the exocytotic fusion machine. EMBO J. 1995;14:224231.

[24] Wiedenmann B, Franke WW, Kuhn C, Moll R, Gould VE. Synaptophysin: A marker protein for neuroendocrine cells and neoplasms. Proc Natl Acad Sci. 1986;83:3500-3504.

[25] Dunel-Erb S, Bailly Y, Laurent P. Neuroepithelial cells in fish gill primary lamellae. $J$ Appl Physiol. 1982;53:1342-1353.

[26] Goniakowska-Witalinska L, Zaccone G, Fasulo S, Mauceri A, Licata A, Youson J. Neuroendocrine cells in the gills of the bowfin Amia calva. An ultrastructural and immunocytochemical study. Folia Histochem Cyto. 1995;33:171-177.

[27] Zaccone G, Lauweryns JM, Fasulo, S, Tagliafierro G, Ainis L, Licata A. Immunocytochemical localization of serotonin and neuropeptides in the neuroendocrine paraneurons of teleost and lungfish gills. Acta Zool. 1992;73:177-183.

[28] Leung AYH, Leung JCK, Chan LYY, Ma ESK, Kwan TTF, Lai KN, Meng A, Liang R. Proliferating cell nuclear antigen (PCNA) as a proliferative marker during embryonic and adult zebrafish hematopoiesis. Histochem Cell Biol. 2005;124:105111.

[29] Yu CC-W, Filipe MI. Update on proliferation-associated antibodies applicable to formalin-fixed paraffin-embedded and their clinical applications tissue. Histochem J. 1993;25:843853.

[30] Kameda Y. Co-expression of vimentin and 19s-thyroglobulin in follicular cells located in the C-cell complex of dog thyroid gland. J Histochem Cytochem. 1995;43(11):1097-1106.

[31] Wen C-M, Cheng Y-H, Huang Y-F, Wang C-S. Isolation and characterization of a neural progenitor cell line from tilapia brain. Comp Biochem Physiol. 2008;149(A):167-180.

[32] Girard JP, Payan P. Ion exchanges through respiratory and chloride cells in freshwater and seawater adapted teleosteans. Am J Physiol. 1980;238: R260-268.

[33] Avella M, Masoni A, Bornancin M, Mayer-Gostan N. Gill morphology and sodium influx in the rainbow trout (Salmo gairdneri) acclimated to artificial freshwater environments. $J$. Exp. Zool. 1987;241: 159-169. 
[34] Goss GG, Laurent P, Perry SF. Evidence for a morphological component in acid-base regulation during environmental hypercapnia in the brown bulhead (Ictalurus nebulosus). Cell Tissue Res. 1992;268: 539-552.

[35] Goss GG, Laurent P, Perry SF. Gill morphology during hypercapnia in brown bulhead (Ictalurus nebulosus): role of chloride cells and pavement cells in acid-base regulation. J. Fish Biol. 1994;45: 705-718.

[36] Laurent P, Dunel S, Chevalier C, Lignon J. Gill epithelial cells kinetics in a freshwater teleost, Oncorhynchus mykiss during adaptation to ion-poor water and hormonal treatments. Fish Physiol. Biochem. 1994;13(5): 353-370.

[37] Perry SF, Fryer JN. Proton pumps in the fish gill and kidney. Fish Physiol. Biochem. 1997;17: 363-369.

[38] Perry SF. The chloride cell: Structure and function in the gills of freshwater fishes. Annu Rev Physiol. 1997;59:325-47.

[39] Goss GG, Perry SF, Fryer JN, Laurent P. Gill morphology and acid-base regulation in freshwater fishes. Comp. Biochem. Physiol. 1998;119A: 107-115.

[40] Laurent P, Chevalier C, Wood CM. Appearance of cuboidal cells in relation to salinity in gills of Fundulus heteroclitus, a species exhibiting branchial $\mathrm{Na}^{+}$but not $\mathrm{Cl}^{-}$uptake in freshwater. Cell Tissue Res. 2006;325: 481-492.

[41] Payan P, Girard JP, Mayer-Gostan N. Branchial ion movements in teleosts, the role of respiratory and chloride cells. In: Hoar WS, Randall DJ, eds. Fish Physiology. Academic Press, Orlando, 1984:39-63.

[42] Shahsavarani A, McNeill B, Galvez F, Wood CM, Goss GG, Hwang P-P, Perry SF. Characterization of a branchial epithelial calcium channel $(\mathrm{ECaC})$ in freshwater rainbow trout (Oncorhynchus mykiss). J Exp Biol. 2006;209: 1928-1943.

[43] Foskett JK, Scheffey C. The chloride cell: Definitive identification as the salt secretory cell in teleosts. Science. 1982;215: 164-166.

[44] Perry SF, Laurent P. Adaptational responses of rainbow trout to lowered external $\mathrm{NaCl}$ concentration: contribution of the branchial chloride cell. J Exp Biol. 1989;147: 147-168.

[45] Wood CM. Branchial ion and acid-base transfer in freshwater teleost fish: environmental hyperoxia as a probe. Physiol Zool. 1991;64(1): 68-102.

[46] Calabro C, Albanese MP, Lauriano ER, Martella S Licata A. Morphological, histochemical and immunohistochemical study of the gill epithelium in the abyssal teleost fish Coelorhynchus coelorhynchus. Folia Histochem Cyto. 2005;43:51-56

[47] Diaz AO, Garcia AM, Devincenti CV, Goldemberg AL. Mucous Cells in Micropogonias furnieri gills: histochemistry and ultrastructure. Anat Histol Embryol. 2001;30:135-139.

[48] Diaz AO, Garcia AM, Devincenti CV, Goldemberg AL. Ultrastructure and histochemical study of glycoconjugates in the gills of the white croaker (Micropogonias furnieri). Anat Histol Embryol. 2005;34:117-122.

[49] Burkhardt-Holm P. Lectin histochemistry of rainbow trout (Oncorhynchus mykiss) gill and skin. Histochem $J$. 1997;29:893-899.

[50] Rojo MC, Blanquez MJ, Gonzalez ME. A histochemical study of the distribution of lectin binding sites in the developing branchial area of the trout Salmo trutta. J Anat. 1996;189:609-621.

[51] Parichy DM, Rawls JF, Pratt SJ, Whitfield TT, Johnson SL. Zebrafish sparse corresponds to an orthologue of c-kit and is required for the morphogenesis of a subpopulation of melanocytes, but is not essential for hematopoiesis or primordial germ cell development. Development. 1999;126:3425-3436.

[52] Lin Z-H, Han EM, Lee ES, Kim CW, Kim HK, Kim I, Kim YS. A distinct expression pattern and point mutation of c-kit in papillary renal cell carcinomas. Modern Pathol. 2004;17:611616.
[53] Erlandsson A, Larsson J, Forsberg-Nilsson K. Stem cell factor is a chemoattractant and a survival factor for CNS stem cells. Exp Cell Res. 2004;301:201- 210.

[54] Bossé P, Bernex F, De Sepulveda P, Salaun P, Panthier J-J. Multiple neuroendocrine tumours in transgenic mice induced by c-kit-SV40 $\mathrm{T}$ antigen fusion genes. Oncogene. 1997;14:2661-2670.

[55] Franchini A, Rebecchi B, Fantin AMB. Gill endocrine cells in the goldfish Carassius carassius var. auratus and their impairment following experimental lead intoxication. Histochem J. 1999;31:559-564.

[56] Jonz MG, Nurse CA. Epithelial mitochondria-rich cells and associated innervation in adult and developing zebrafish. $J$ Comp Neurol. 2006;497:817-832.

[57] Burleson ML, Mercer SE, Wilk-Blaszczak MA. Isolation and characterization of putative $\mathrm{O}_{2}$ chemoreceptor cells from the gills of channel catfish (Ictalurus punctatus). Brain Res. 2006;1092:100-107.

[58] Jonz MG, Nurse CA. New developments on gill innervation: insights from a model vertebrate. J Exp Biol. 2008;211:23712378.

[59] Barreda DR, Hanington PC, Walsh CK, Wong P, Belosevic M. Differentially expressed genes that encode potential markers of goldfish macrophage development in vitro. Dev Comp Immunol. 2004;28:727-746.

[60] Castro R, Piazzon MC, Noya M, Leiro JM, Lamas J. Isolation and molecular cloning of a fish myeloperoxidase. Mol Immunol. 2008;45:428-437.

[61] Reite OL. Mast cells/eosinophilic granule cells of teleostean fish: a review focusing on staining properties and functional responses. Fish Shellfish Immunol. 1998;8:489-513.

[62] Reite OB, Evensen O. Inflammatory cells of teleostean fish: A review focusing on mast cells/eosinophilic granule cells and rodlet cells. Fish Shellfish Immunol. 2006;20:192-208.

[63] Matsuyama T, Lida T. Degranulation of eosinophilic granular cells with possible involvement in neutrophil migration to site of inflammation in tilapia. Develop Comp Immunol. 1999;23: 451-457.

[64] Barnett RR, Akindele T, Orte C, Shephard KL. Eosinophilic granulocytes in the epidermis of Oreochromis mossambicus gill filaments studied in situ. J Fish Biol. 1996;49: 148-156.

[65] Reite OB. Mast cells/ eosinophilic granule cells of salmonids: staining properties and responses to noxious agents. Fish Shellfish Immunol. 1997; 7: 567-584.

[66] Mulero I, Sepulcre MP, Meseguer J, García-Ayala A, Mulero V. Histamine is stored in mast cells of most evolutionarily advanced fish and regulates the fish inflammatory response. PNAS. 2007:104:19434-19439.

[67] Flano E, López-Fierro P, Razquin BE, Villena A. In vitro proliferation of eosinophilic granular cells in gill cultures from rainbow trout. Fish Shellfish Immunol. 1997;7: 519-521.

[68] Dang Z, Lock RAC, Flik G, Wendelaar-Bonga SE. Metallothionein response in gills of Oreochromis mossambicus exposed to copper in fresh water. Am $J$ Physiol. 1999;277:R320-R331.

[69] Uchida K, Kaneko T, Tagawa M, and Hirano T. Localization of cortisol receptor in branchial chloride cells in chum salmon fry. Gen Comp Endocrinol. 1998;109:175-185.

[70] Lee W, Huang C-Y, Lin H-C. The source of lamellar mitochondria-rich cells in the air-breathing fish, Trichogaster leeri. J Exp Zool. 2008;309A:198-205.

[71] Robertson JC, Hazel JR. 5c-Nucleotidase and alkaline phosphodiesterase activities in trout gill localize to endothelial (pillar) cells. J Exp Biol. 1998;201:2011-2019.

Submitted: 15 September, 2009 Accepted after reviews: 19 January, 2010 